\title{
The Famous but Difficult Psalm 90:10*
}

\author{
Aron Pinker (MARYLAND, USA)
}

\begin{abstract}
Application of standard text-critical tools to the difficult Ps 90:10 results in the interpretation: The days of our vigor [are] seventy years, [or] Our years with might [are] eighty years, And their pride [is] vexation and sorrow. We fade quickly, and we rattle . . . It is being claimed that the last colon of MT is a minor textual corruption

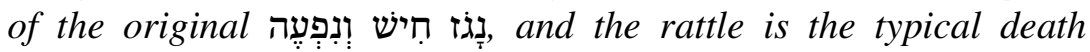
groan.
\end{abstract}

Keywords: Ps 90:10, longevity, transience, death rattle.

\section{A INTRODUCTION}

Chapter 90, the first in the fourth book of the Book of Psalms, has been described by Jens as

A puzzling text, contradictory and dark, hopeful and somber, merciless and gentle. A song of dying and a word of life-a psalm marked equally by fear and trust, of terrible death and tender friendliness, lament and praise, wrathful judgment and hymnal eulogy. ${ }^{1}$

It gained much notoriety because parts of two of its verses (vv. 4 and 10) became colloquial elements.

Chapter 90 is also distinguished by a heading that identifies its author as the venerated Israelite leader Moses. ${ }^{2}$ The heading indicates that the psalm is a "prayer" (תפלה). Relatively recent studies seem to concur with this assessment. Commentators described this psalm as dealing with God's and man's time, and as lamenting in esse the transience of human beings. ${ }^{3}$ A number of scholars, however, noted that reference to "seventy years" (v. 10) is usually associated in the Tanach with a national calamity (Jer 25:11-12, Zech 1:12). This consideration, among others, led them to the perception that ch. 90 is "a lament at the

* To cite: Aron Pinker, "The Famous but Difficult Psalm 90:10," OTE 28, no. 2 (2015): 497-522. DOI: http://dx.doi.org/10.17159/2312-3621/2015/v28n2a15

$1 \quad$ Walter Jens, "Psalm 90: On Transience," LQ 9 (1995): 177-189 (177).

2 Moses' name occurs in a heading only here. It occurs also in chs. 90-106. Already Augustine opined that Moses could not have written the psalm because it does not contain any distinctive Mosaic expressions. Cf. John Goldingay, Psalm 90-150 (vol. 3 of Psalms; BCOT; Grand Rapids: Baker, 2008), 23, note 28.

3 Thomas Krüger, "Psalm 90 und die Verganglichkeit des Menschen," Bib 75 (1994): 191-219. 
community's historical experience in which wisdom have been utilized to formulate a lament that leads to a plea."4

This study is focused on the well-known v. 10 in ch. 90, which reads,

The span of our lives is seventy years, Or, given the strength, eighty years;

But the best of them are trouble and sorrow.

They pass by speedily, and we are in darkness,

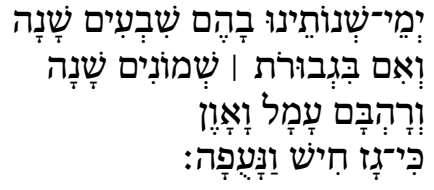

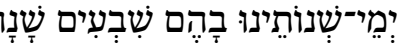

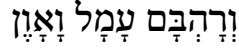

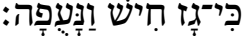

and has posed considerable difficulties to commentators since the time of the Versions. Seybold simply observes that: "der Sinn dieses Verses ist Dunkel."

Whatever thematic perspective is adopted, the strange occurrence of the pronominal בָָה in the first colon baffles. Duhm observed:

Wenn der Dichter בֶָהם, ihrer sind, geschrieben hätte, so hätte er sich erstens Schlecht un prosaisch ausgedruckt und zweitens etwas Unrichtiges gesagt, den "unser" Leben währt keineswegs im durchschnitt, sondern nur in den selteren Fällen siebentzig Jahre. ${ }^{6}$

Reider, a more recent scholar, noted that

בהם To anyone familiar with biblical diction it must be evident that in Ps. xc 10 cannot be pronominal, and yet the ancient versions render it so. . . . Emendations, of course, are not lacking: some suggest גבהם גביים; but it is obvious that none of these can be the original reading. ${ }^{7}$

The preceding NJPS translation deletes בָּהם notes that the meaning of

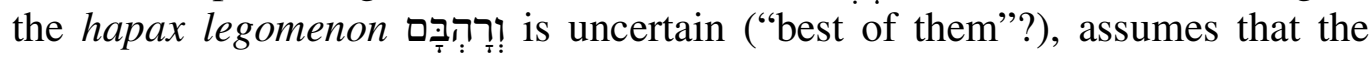

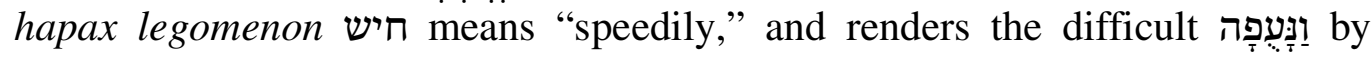

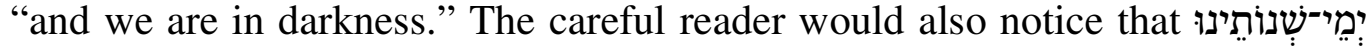

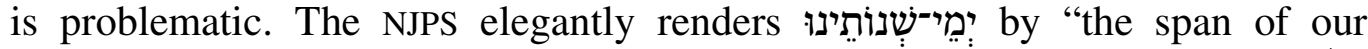
lives." However, the Hebrew equivalent of "the span of our lives" is כל ימי חיינו

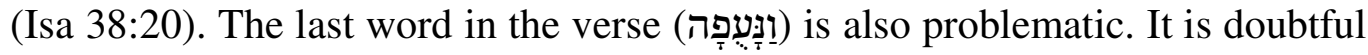
that the NJPS translation "and we are in darkness (equivalent to Hebrew ונהיה (בעיפה "reflects ונעפה.

4 Goldingay, Psalms 3, 22. Cf. Richard J. Clifford, "Psalm 90: Wisdom Meditation or Communal Lament," in The Book of Psalms, Composition and Reception (ed. Peter W. Flint and Patrick D. Miller; VTSup 99; Leiden: Brill, 2005), 190-205.

5 Klaus Seybold, “Zu den Zeitvorstellungen in Psalm 90,” TZ 53 (1997): 103.

6 D. Bernhardt Duhm, Die Psalmen erklärt (Freiburg: Mohr, 1899), 226.

7 Joseph Reider, "Etymological Studies in Biblical Hebrew," VT 2/2 (1952): 123. 
The purpose of this study is to suggest resolution of the noted difficulties using standard text-critical tools. In this context, it is being argued that 10a $\alpha-10 \mathrm{a} \beta$ is a conflation of two common sayings: ימי כחיזנו שבעים שנה (the days of our vigor [are] seventy years), and שנותינו בגבורת שמונים שנה (Our years

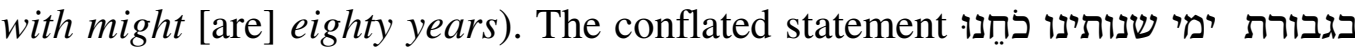
בגבורת was meant by the author to be perhaps understood: "The days, years [with/in] vigor, [are] seventy years. And, if with might, [are] eighty years." It is, however, an awkward Hebrew sentence; as conflated verses are usually. In final evolution of the verse, a copyist might have incorrectly copied כחנו instead of Such an error would have been in particular likely if the copying was from a densely written scroll, and it was probably enhanced by the awkwardness of the conflated text. Finally, the last colon of MT is understood as being a minor textual corruption of the original נָגז חִיש וְנְפְעֶ (We fade quickly, and we rattle... ).

\section{B ANALYSIS}

\section{Ancient Versions}

It seems that in context with vv. 7-9 Septuagint understands v. 10 as referring to the transience of human beings, which is caused by divine corrective measures. It renders v. 10:

[As for] the days of our years, in them are seventy years; and if [men should be] in strength, eighty years; and the greater part of them would be labor and trouble; for weakness overtakes us, and we

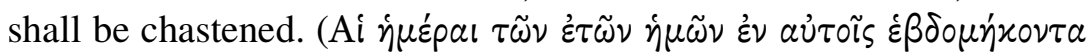

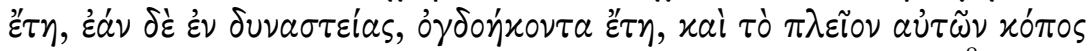

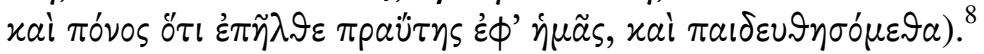

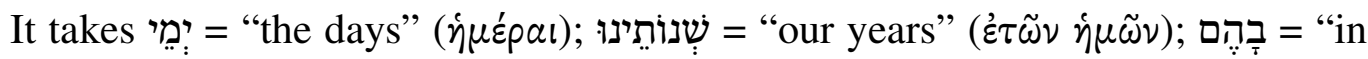

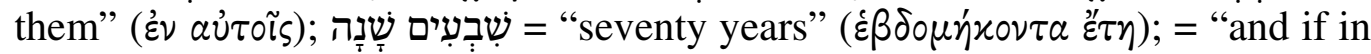

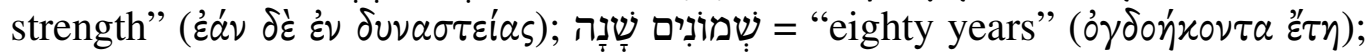

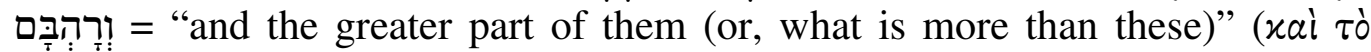

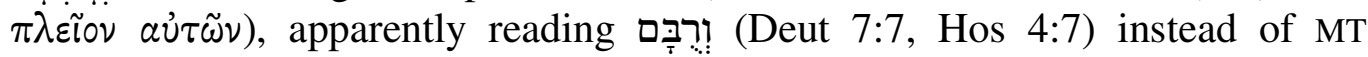

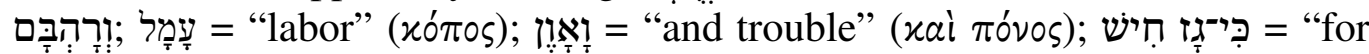

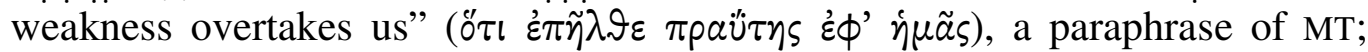

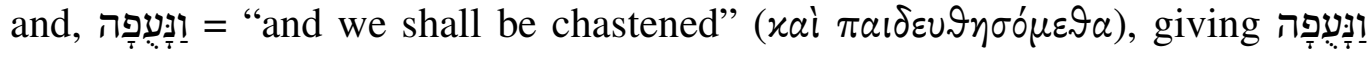
an unattested meaning.

Targum (Jonathan) understands v. 10 as describing man's longevity in this world. It translates:

8 Lancelot C. L. Brenton, The Septuagint with Apocrypha: Greek and English (Peabody: Hendrickson, 1987), 754. 
The days of years in this world [are] seventy years summoning strength, and if mighty eighty years, and they [are] mostly labor and lying to debtors, for they pass in a hurry and fly as morning (יומין שמוזין שנותנא בעלמא הדין שובעין שנין מתאלמין ואין בגבורתא תמנן שנין

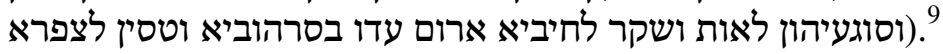

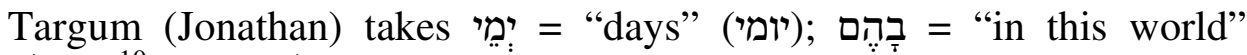
(בעלמא הדין); "summoning strength"; as the Septuagint takes

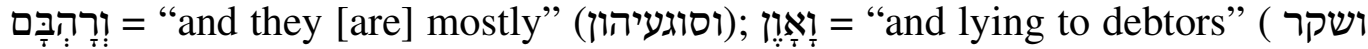

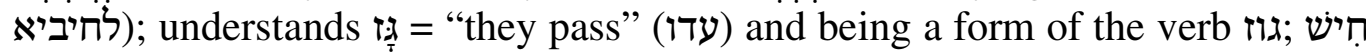

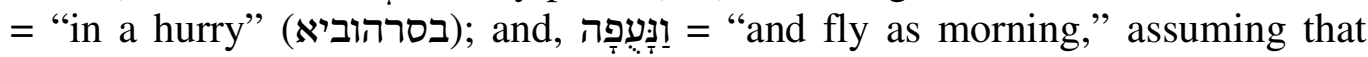

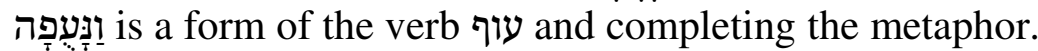

Peshitta considers v. 10 as describing the human condition. It translates: "The years of our life are three score and ten; and if by reason of strength they be fourscore years, yet most of them are labor and sorrow; for life is soon cut

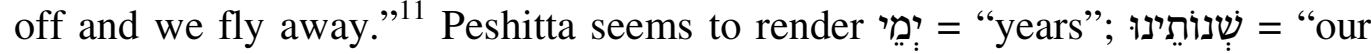

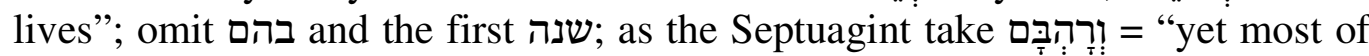

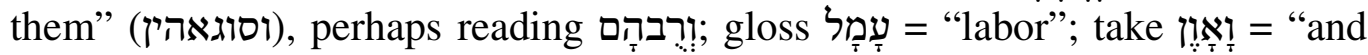
sorrow"; add the word "life" to the last colon; understand $=$ "cut off" and being a form of the verb גזה מזכ; assume that the hapax legomenon חיש = "soon" (מוככא), perhaps understanding חיש as "pain and trouble"; and, translate

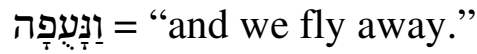

Finally, the Vulgate takes v. 10 as a statement of promise; at the end of life mildness will set in and man would be chastened. It renders:

The days of our years in them are threescore and ten years. But if in the strong they be fourscore years: and what is more of them is labor and sorrow. For mildness is come upon us: and we shall be corrected. (dies annorum nostrorum in ipsis septuaginta anni si autem multum octoginta anni et quod amplius est labor et dolor quoniam transivimus cito et avolavimus). ${ }^{12}$

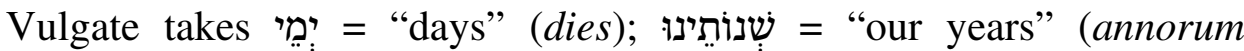

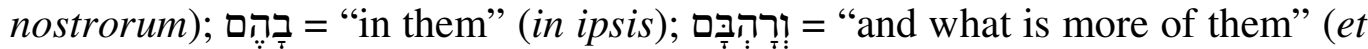

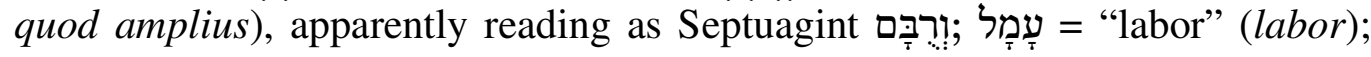

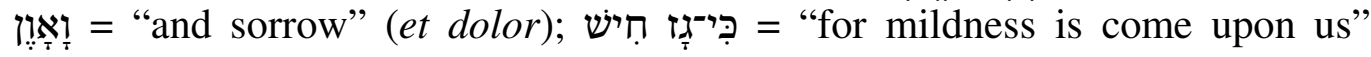

9 Jastrow, 1298b. Jastrow suggests the more logical reading כצפרא, which is adopted in the translation.

10 Jastrow, 71b. Jastrow raises the possibility that בהם is represented by מתאמין "summoning strength."

11 George M. Lamsa, Holy Bible from the Ancient Eastern Text (San Francisco: Harper \& Row, 1933), 632.

12 The Vulgate translation into Latin is based on a Hebrew manuscript (Psalmi iuxta Hebraica), and the Douay-Rheims translation into English was used. 
(quoniam transivimus cito), a meaning that cannot be anchored in the MT; and,

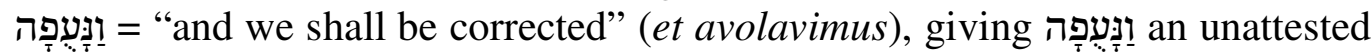
meaning.

It seems that most of the Versions understand ימימ: as "the days"; indeed, being followed by שׁׁנוֹתֵינוּ that would be a reasonable translation. No clear guidance is provided by the Versions on the treatment of the pronominal בהם All of

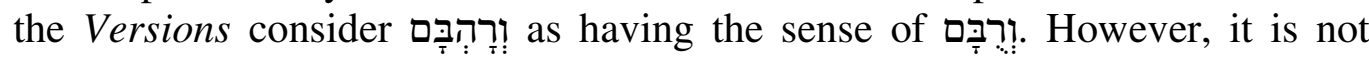
clear whether they had a different Vorlage, or considered ורהם simply having an extra $ה$. The last word in the verse (וֹנְעָפָָה), however, appears to have presented considerable challenges, both textual and thematic.

\section{Classical Jewish Exegesis}

Classical Jewish exegetes were concerned with the disagreement between the statement in v. 10a and Moses' longevity of 120 years, and tried directly or implicitly to explain it. Rashi (1040-1105) connects thematically v. 10 to vv. 89. ${ }^{13}$ He understands בהם as referring to the עלמנו tioned in v. 8; explaining: These years, with these iniquities (עונתינו) and these sins of youth (עלמנו), they are seventy years. And if one's years (ימו) prevailed much they are eighty years. And the honor and rule (ורהבם) that one acquires in those years is inconsequential (עמל ואון) because of God's anger (נורם ) בעברתך כלינו)

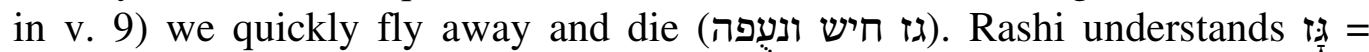
"they pass" and being a form of the verb (Nah 1:12, Num 11:31). He seems to be implying that man's life is usually not longer than 70 or 80 years because of his sinning; that is, they could have been more (like those of Moses) otherwise.

Ibn Ezra (1089-c. 1164) notes that Moses' living to 120 years cannot be used to deny him the authorship of this psalm. Moses simply summed up the experience of previous and his generation. Ibn Ezra has nothing to say about the first two cola and in particular about the awkward בהם. He assumes that "(days of) power and strength," which are the days of adulthood, and is undecided whether נעפה refers to "wandering from place to place as a bird," "we shall fly to dwell in the netherworld," or "as a blink will be the days." Qimchi (1160-1235) observes that Moses spoke not about his self but the majority of people. The generations in exile complain that they would not experience salvation because it is being delayed and life being so short. Qimchi does not explain the oddity of בהם. He takes רהבם = "their strengths (of the days)" (חוזק הימים), explaining "even if one is ripe in years, they are but toil and iniquity, and would not last"; for quickly as the bird flies we shall die. This metaphor is unusual in the Tanach.

13 The commentaries of classical Jewish exegetes are drawn from Rabbinic Bibles. 
Menachem Meiri (1249 - c. 1310) understands v. 10a as saying: “The days of our life, few among them (בהם) that are not the usual seventy years. And if so naturally disposed, eighty years."14 Meiri explains: "Though Moses lived to 120 years he spoke prophetically about the future and in particular about the exile." In his view, רהבם = "the pride and power" (הגאות והשררה) of

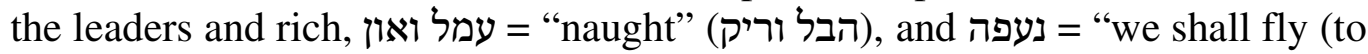
the grave)." Sforno (1470-1550) attaches v. 10a to the preceding verse, takes

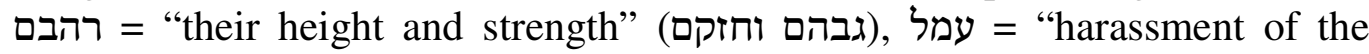

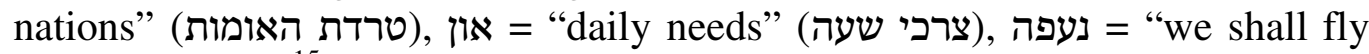
(from this life).",

While classical Jewish exegesis has its parochial bent, it is obvious that it struggled in its interpretation of v. 10 no less than the Versions. The interpretations are tainted by personal experiences, but do not offer original insights into the stated textual difficulties. As it will become clear in the next section, modern exegesis did not fare any better.

\section{$3 \quad$ Modern Exegesis}

Modern exegesis found v. 10a challenging. The verse has been traditionally understood as a statement on life expectancy. However, what is known on the state of medicine in antiquity defies the stated longevity. Tate felt that "conditional clauses in 10a and 10b seem more plausible," making it a suitable addendum to the material in vv. 7-9. ${ }^{16}$ Briggs, however, deletes v. 10a. In his view

A glossator inserted a prosaic statement as to the usual duration of human life: In them are seventy, or if, by reason of extraordinary might, eighty years. But it interrupts the thought and destroys the measure of the original. ${ }^{17}$

Verse 10, when taken by itself, seems to be a reflection about the transience of human life and a pessimistic assessment of its significance. Delitzsch, a major 19th century commentator, translated v. 10 thus:

Die Tage unsere Jahre-ihre Summe ist siebenzig Jahr

Und, wenn gevaltig viel, achtzig Jahr,

Und ihr stoltz is Mühsal und nichtigkeit,

14 Ha-Meiri (המאירי), Mikraot Gedolot (Jerusalem: Even Israel, 1992), 75.

15 Sforno (ספורנו), Mikraot Gedolot (Jerusalem: Even Israel, 1992), 689.

16 Marvin E. Tate, Psalms 51-100 (WBC 20; Dallas: Word Books, 1990), 433. It is fairly common to encounter in the Tanach conditional statements without an indicator (א).

17 Charles A. Briggs, The Book of Psalms (vol. 2; ICC; Edinburgh: T \& T Clark, 1960), 275. 
Den es fuhr vorüber eilends und wir flogen dahin. ${ }^{18}$

We shall use this translation as a baseline for our analysis of modern exegesis on v. 10.

- ימי ימי = "the days of our years" (Die Tage unsere Jahre). ימי־שנותינו יום יום יום could also mean "year" (1 Sam 2:19, Exod 13:10, Judg 11:14, 21:19, Isa 32:10). If יִמי are "days," then their number is usually more than seventy. If ימימי are "years," then the phrase becomes a meaningless repetition: "year of our years." Whenever the phrase ימי שני occurs in the Tanach, referring to a specific number, it is always followed by (Gen 25:7,

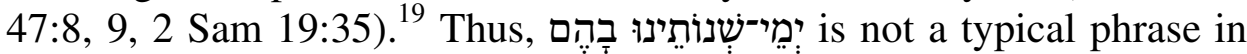
the Tanach; indeed, it never occurs.

Relying on Gen 47:8, some commentators assume that ימֵי־שְנוֹתֵינוּ means "the days of our life." שנותינו could have the sense "our life," which is unattested in the Tanach. ${ }^{21}$ De Wette assumed a comma after ימי־שנותינו that implied a sense "as to the days of our years." 22 In this case one would anticipate a qualitative description to follow.

Müller says:

$j^{e} m \hat{e}-\breve{s}^{e} n \hat{o} t e ̂ n u \hat{u} »$ die Tage ihrer (einzelnen) Jahre« am Anfang von V. 10 ist Glosse, die als eine Art casus pendens klären will, worauf sich das Pronominalsuffix des nächsten Wortes bezieht, und dazu die Hauptnomina von V. 9 aufnimmt und miteinander verbindet. ${ }^{23}$

This would shift all the problems associated with ימֵי־שְׁנוֹתֵינוּ בֶהם to v. 9b. Moreover, as Schreiner says: yemê-senôtênû als 'Glosse' streichen, hieße, den Satz v. 10a $\alpha$ des Subj. berauben." ${ }^{24}$ Finally, it is doubtful that a reader would have recognized this complicated syntax. Schreiner believes that "Der Ausdruck meint das, was wir unsere 'Lebenszeit'

18 Franz Delitzsch, Biblischer Kommentar über die Psalmen (5th ed.; Leipzig: Dörffling Franke, 1894), 590.

19 The open-ended ימי־שניו can be found in Qoh 6, where it clearly refers to the days of a man's life. Cf. Aron Pinker, "The ligature ע ע ע in Qohelet 6.3," BT 62/3 (2011): 151-164.

20 Amos Hacham, תהילים חלק ב' (Jerusalem: Mosad HaRav Kook, 1987), 164-165.

21 Only Prov 5:9, where הודך parallels, might (perhaps) have this sense.

22 Wilhelm M. de Wette, Commentar über die Psalmen (4th ed.; Heidelberg: Mohr, 1836), 504.

23 Hans-Peter Müller, "Der 90. Psalm: Ein Paradigma exegetischer Aufgaben," ZTK 81/3 (1984): 274, note 49.

24 Stefan Schreiner, “Erwägungen zur Struktur des 90. Psalms,” Bib 59/1 (1978): 85. 
nennen (vgl. Gen 47,8), wie ja der Plural yāmim des öfteren an die Stelle unseres Begriffes 'Zeit' tritt.,"25

- בהם = "their sum is" (ihre Summe). Meir Leibush ben Yechiel Michel (Malbim, 1809-1879) understands בהם as referring to the normal life span of seventy years; namely "if our years are in them (בהם), in the regular years (the word שנותנו referring שהם to, they would be seventy years." ${ }^{, 26}$ This nuance of שנותינו is, however, not attested in the Tanach. Delitzsch explains: "es sind darin befaßt 70 Jahre, sie begreifen, belaufen sich auf so viel.",

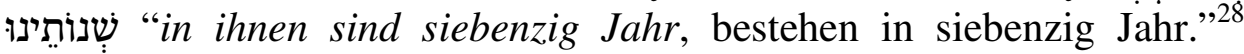
How-ever, that הם = בהם, is not attested in the Tanach, though some consider Ps 65:5 ביה) and Ps 118:7 (בעזרו) as supporting the notion that a $ב$ prefixed noun could have the same meaning as the noun. Moreover, it suggests the incorrect notion that man's life span is at least seventy years.

Reider notes that when both first two colons are considered it

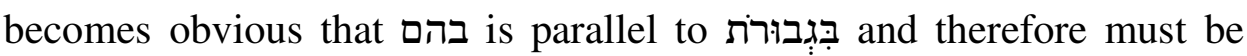
either synthetic or antithetic to it. In his view,

הם has been misunderstood as a pronoun, while it should be construed as a noun. Assuming the root הים or "discomfit," we might read either בהם, if med. ו, or בהם , if med. ', and render "in discomfiture." 29

This suggestion leads to the phrase "The days of our years in discomfiture."

Dahood takes בהם = "then (i.e., as a consequence of God's fury)." He says:

For the meaning of בהם "hen, thereupon" see Isa 48:14 and Job 22:21. Its components seem to be בָ, "from, after," and "these," hence "after these, then." There is a possible occurrence in UT, 137:24, bhm yg ' $r b^{\prime}$ 'al' then Baal shouts. ${ }^{30}$

25 Schreiner, "Erwägungen," 85 note 31. However, in the quoted source the phrase ימי שני.

26 Malbim, Mikraot Gedolot (Jerusalem: Even Israel, 1992), ad loc.

27 Delitzsch, Biblischer, 590. In support of this meaning, Delitzsch points to Pesiq. Rab Kah. 20a where יש בהם is used. Obviously, יש בהם בהם.

28 De Wette, Commentar, 504.

29 Reider, "Etymological," 123.

30 Mitchell J. Dahood, Psalms 1-50 (vol. 1 of Psalms; AB 16; Garden City: Doubleday, 1968), 122. 
However, Dahood's etymological explanation is questionable, and the biblical sources cited in support are not compelling.

Schreiner finds the referents for בהם in vv. 7-9 and that the "grammatisch-syntaktischen Richtigkeit des bāhäm in v. 10a $\alpha$ ist also nicht zu zweifeln.” He says:

"Unsere Lebenszeit" umfaßt 70 Jahre, und zwar bāhäm "durch sie." Das Suffix hier bezieht sich nicht auf die yāmîm, sondern knüpft an das an, was vorher an Gründen für die Kurzlebigkeit des Menschen aufgezählt worden ist: appäkā, hamät ${ }^{e} k \bar{a}$ (v. 7), " "wônōtênû, “'ümēnû (v. 8), 'abrātäkā (v. 9). "Durch diese" wird die Lebenszeit auf 70 Jahre begrenzt. ${ }^{31}$

However, when the preposition $ב$ has a causal force it is never followed by a pronominal.

Müller says that "bhm ist mit Duhm, Gunkel, BHS u. a. zu gobhām »ihre Größe «." "32 This contention is not accurate, and the meaning "Größe" for גָּבָה is not attested in the Tanach. Hayot notes that

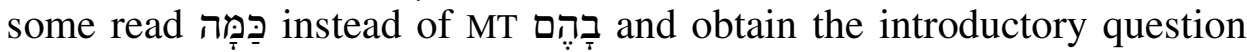
ימי שנותינו כמה While the emendation of כמה to בהם is minor, the resulting question is not attested in the Tanach, though it occurs frequently in the Talmud (e.g., bHagigah 11a). ${ }^{33}$ Krüger translates the three letter word בהם by "(betragen) von sich aus." In his view "Das Suffix 3. masc. pl. in בהם wird am ehesten auf ימי (שנותינו) zu be ziehen und die Wendung in Opposition zu בגבורת zu interpretieren sein."34 Seybold has for בהם "unter ihnen," but such sense the preposition is not attested in the Tanach. ${ }^{35}$

Hacham observes that בהם makes ימי שנותינו בהם שבעים שנה into a specification sentence that means: In the days of our life there are seventy years. ${ }^{36}$ However, this sense can be obtained more cogently by writing בימי שנותינו שבעים שנה. Goldingay notes that "one might take the proposition in bāhem as $b$ of identity (beth essentia)."37

31 Schreiner, "Erwägungen," 85.

32 Müller, "Der 90. Psalm," 274 note 49.

33 Zvi P. Hayot, ספר תהילים (Jerusalem: Makor, 1970 [repr. of 1st ed. 1902]), 200.

34 Thomas Krüger, "Psalm 90 und die "Vergänglichkeit des Menschen," Bib 75/2 (1994): 194.

35 Seybold, "Zeitvorstellungen," 102.

36 Hacham, תהילים,164-165.

37 Goldingay, Psalms 3, 20. Goldingay renders v. 10: "The days of our years in themselves are seventy years, // or, with strength eighty years. // But their boisterousness has been toil and trouble, // because it has passed quickly and we have 
506 Pinker, "Psalm 90:10," OTE 28/2 (2015): 497-522

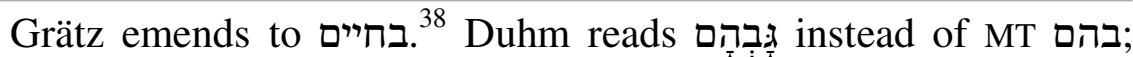
obtaining "Ihre Höche sind siebenzig." 39 However, in the Tanach the

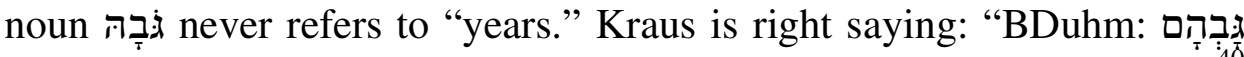
('ihr Gipfel') wäre eine Bild, das dem Hebräer fremd sein dürfte."40 Weiser apparently omits בהם in his rendering of v. 10a by "The years of our life are threescore and ten." ihnen') ist schwer verständlich und wohl metri causa zu streichen." Tate felt that "the language in 10a need not be changed though it is awkward. The masculine suffix of 'in them' refers to the 'days of the years'; not to the feminine "years' alone."43 Hossfeld and Zenger take " = "but," which is unattested in the Tanach.

- "seventy years" (siebenzig Jahr). ${ }^{45}$ Andersen notes that 'seventy years' could hardly be taken as the normal average age ${ }^{46}$ rather it could be regarded as the normal limit of human life, and only a few individuals would live to see their seventieth birthday. ${ }^{47}$ An average life span of seventy was attained in relatively recent years, and that only in Western modern countries. However, the ancients had sufficient experience with various age-groups to meaningfully categorize them. For instance, a tablet from Sultantepe categorizes the stages of life from age 40 through age 90: 40_lalutu ("prime of life"); 50_umu kurutu ("short life"); 60—metlutu ("maturity"); 70—umu arkutu ("long life"); 80_sibutu ("old age"); and, 90_littutu ("extreme old age"). ${ }^{48}$ Zerafa

flown." Cf. Johannes Schnocks, Vergänglichkeit und Gottesherrschaft (Berlin: Philo, 2002), 92-93.

38 Heinrich Grätz, Kritischer Kommentar zu den Psalmen (Breslau: Schottlaender, 1882), ad loc.

39 Duhm, Psalmen, 226.

40 Hans-Joachim Kraus, Psalmen (vol. 2; Neukircchen-Vluyn: Neukirchener, 1966), 628.

41 Artur Weiser, The Psalms: A Commentary (London: SCM Press, 1971), 594.

42 Kraus, Psalmen 2, 628.

43 Tate, Psalms 51-100, 433.

44 Frank-Lothar Hossfeld and Erich Zenger, A Commentary on Psalms 51-100 (vol. 2 of Psalms; Minneapolis: Fortress Press, 2005), 421.

45 Gabriel Barzilai, שבעים שנה' מירמיהו ועד דאניאל: סמנטטיקה, פרשנות ואפוקליפטיקה', Bבעים שנה שבעה' 59/2 (2014): 45. Many modern commentators note that the phrase refers to a national calamity; a period of communal punishment, destruction, and exile. Barzilai argues that an analysis of the phrase שבעים שנה in Jer 25:11-12, 29:10, and Isa 23:15-17 links it to the domain of royal dynasties' continuity and fall, rather than exile.

46 Ludwig Köhler, Der hebräische Mensch: eine Skizze (Tübingen: Mohr, 1953), 42-46.

47 Arnold A. Andersen, Psalms 73-150 (vol. 2 of The Book of Psalms; Grand Rapids: Eerdmans, 1992), 653.

48 Oliver R. Gurney and Jacob J. Finkelstein, The Sultantepe Tablets (vol. I/II; London: British Institute of Archaeology at Ankara, 1957/1964), 400, revised lines 45-47. 
argues that "The literary biblical evidence uniformly endorses Ps 90,10 [and hence, a seventy-year life expectancy] as a realistic statement."49 However, a "long life" was rarely achieved in ancient Israel. For instance, with the sole exception of David (1 Chr 29:28), none of the other Davidic kings reached the age of seventy. Malamat argues that in Ancient Israel a person could conceivably expect to live to see his great grandchildren. In his view "The assessment of longevity by a standard of four generations matches the Bible's realistic appraisal of maximal life expectancy." ${ }^{, 50}$ A span of seventy years would allow seeing a maturing fourth generation. ${ }^{51}$

- "and when very many" (Und, wenn gevaltig viel), which de Wette characterizes as being "ohne beleg aus dem Sprach-

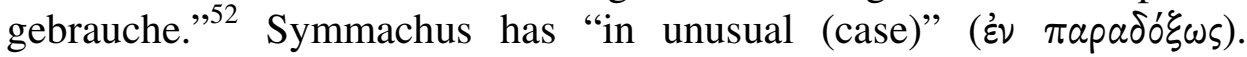
Delitzsch explains that

גבורת bed. 71,16 Vollkraft, hier Vollmaß. Siebzig, höchstens achtzig Jahr waren der Durchschnittsbetrag des äußersten Lebensalters, zu velchem die in der Wüste austerbende Generation gelangte. ${ }^{53}$

De Wette has a more literal interpretation for בגבורת "mit Kraften, mit starker Lebenskraft." ${ }^{, 5}$

A similar division of life into stages occurs in $b$. Mo'ed Qat. (28a). It is notable that there too a span of fifty is considered short life and the term מיתת כרת is used. The Gaon of Vilnius (GR'A) found support for the Talmudic perception that regular lonליקוטי הגר"א 10+40+10. Cf. Ha-GRA, ימי לי Mikraot Gedolot (Jerusalem: Even Israel, 1992), 19. A more detailed division is presented in Pirqe Aboth 5:21.

49 Pietro P. Zerafa, “The Old Testament Life Span,” Ang 65 (1988): 116.

50 Avraham Malamat, "Longevity: Biblical Concepts and Some Ancient Near Eastern Parallels," in History of Biblical Israel: Major Problems and Minor Issues (ed. Avraham Malamat; Leiden: Brill, 2001), 394. Malamat concludes that "the Bible presents a factual assessment of biological age, mentions exceptionally long-lived individuals; it also offers stock descriptions of the hardships and infirmities of old age (see especially Ecc. 12:1-7; cf. II Sam. 19:36, and Ps. 71, among others)." Cf. Malamat, "Longevity," 395.

51 Köhler, Der hebräische Mensch, 48ff. Köhler estimates that in ancient Israel, a person could become a father at 19 , and consequently be 57 at the birth of his first great-grandchild.

52 De Wette, Commentar, 504.

53 Delitzsch, Biblischer, 590. Delitzsch assumes that seventy, at most eighty years, was the average of the extreme age, which the Desert-dying generation could reach. However, it is doubtful that the psalm was penned by Moses the Exodus and that people could live that long in the harsh desert conditions. It is notable that only 40 years were required for a brand new generation to emerge. 
Dahood gives ואם בגבורת the colloquial sense "and if Heaven wills." 55 In Schreiner's view, "Die Verlängerung des Lebens auf 80 Jahre ist allein der Unterstützung durch die 'Taten YHWHs' zu verdanken." taten," explaining that "Bei גבורת dürfte an 'Krafttaten' Gottes zu denken sein" (Ps 20:7, 106:2, 150:2, Deut 3:24). ${ }^{57}$ The words of Barzillai to David, when David invited him to stay with him in Jerusalem as a reward for his help during Absalom's resurrection, give us a glimpse on the hardship of being old even for aristocrats. He says:

I am this day eighty years old; and I cannot discern between luxury and simple living; neither can your servant taste what he eats or what he drinks. Nor can I hear anymore the voice of singing men or singing women. Why then should your servant be a burden to my lord the king? (2 Sam 20:35).

- "eighty years" (achtzig Jahr). The numerical escalation "seventy ... eighty" is not a simple poetic device for delimiting. ${ }^{58}$ Eighty years is not considered in the Tanach as being an unusually long life span. In Genesis (6:3) the maximal human longevity is set by the symbolic number $120=3 \times 40$. Pinker suggested that

the termination of the rainy season in Babylon and the subsequent regeneration of the soil led to the notion that 40 was the right age for significant beginnings. From this evolved the concept of 40x2 as the length of human life, and $3 \times 40$ as the utmost length of human life. ${ }^{59}$

Isaiah (65:20) and Ben Sira (18:9) imply that a hundred years count as a long life. ${ }^{60}$

- רהָב "and their pride" (Und ihr stoltz). The noun a hapax legomenon, but the verb רָָהב "act stormily, boisterously, arrogantly," is well attested in the Tanach and cognate Semitic languages. Delitzsch does not accept the possibility that רהבְּם is a corruption all the ancient Versions apparently read. In his view, the noun רַהָב (רהַב (here)

54 De Wette, Commentar, 504.

55 Mitchell J. Dahood, Psalms 51-100 (vol. 2 of Psalms; AB 17; Garden City: Doubleday, 1968), 321 and 325.

56 Schreiner, "Erwägungen," 85. Shreiner renders the first two cola: "Unsere Lebenszeit beträgt durch sie 70 Jahre, wenn aber 'Gott will' 80 Jahre."

57 Krüger, "Psalm 90," 194. Cf. Schreiner, "Erwägungen," 85.

58 Dahood, Psalms 2, 325. Dahood seems to be thinking that we have here a typical numeric escalation.

59 Aron Pinker, "The Number 40 in the Bible," JBQ 22/3 (1994): 163-172.

60 The maximal age according to various Egyptian sources was 100 years, while the ideal lifetime was 110 years; i.e., a century plus a serene bonus granted to the worthy. 
means "impetuosity, violence, vehemence" (Ungestüm) and in particular grandiose and ostentatious acts "das großthuerische prahlerische Auftreten Iob 9,13. Jes. 30,7."61 Duhm renders רהבם by "their blaster" (ihr Gephrale). ${ }^{62}$ Westerman is undecided with respect to רהבם "die Fülle (oder Höhe?, das Wort ist unsicher." gance," instead of MT רָּר:

\section{Müller suggests}

$w^{e}$ rohbām »und ihr Drängen « am Anfang der folgenden Zeile, zu ergänzen (sinngemäß: »ihr Maß«); das masc. Suffix kann sich dabei tatsächlich zumindest nicht allein auf šānênû »unsere Jahre« beziehen, da šānîm wie šānā fem. ist (vgl. štajim šānîm 2Sam 2, 10). ${ }^{65}$

Schreiner understands רהבם as "der Stolz des Lebens."66 Krüger has for ורהבם "but its urging" (aber ihr Drängen), which gives a thematically awkward text. ${ }^{67}$ Seybold says:

Ohne es letzlich beweisen zu können, möchte ich vermuten, dass רב I, vielmehr von der Wurzel רהב abzuleiten ist, der nach den semantischen Äquivalenten offenbar die Grundbedeutung «eilen, drängen, stürmen» eigen ist, so dass das Nomen רהב-ein Hapaxlegomenon—auf eine schnelle Bewegung zu beziehn ist. ${ }^{68}$

However, the notion of "quick movement" does not correspond עמל ואון whell to עמל ואון, or to v. 10b, as Seybold suggests. The notions do not contain a time element, and attaching רהבם to v. 10b would overload it with repetitions of "quick movement."

Goldingay notes that

For the hapax rōhab, Versions imply rōhab "breadth" (but it is doubtful whether this more common word makes better sense; the

61 Delitzsch, Biblischer, 591. However, cf. Aron Pinker, "Isaiah 30,7b," BN 136 (2008): 31-44.

62 Duhm, Psalmen, 226.

63 Claus Westermann, "Das 90. Psalm," in Forshung am Alten Testament (ed. Claus Westermann; München: Chr. Kaiser, 1964), 348.

64 Dahood, Psalms 2, 325.

65 Müller, "Der 90. Psalm," 274 note 49. In his view " w rohbām bezieht sich wie 'gobhām' V. 10a auf jāmenûl/ šānênû in V. 9."

66 Schreiner, "Erwägungen," 86. Shreiner renders the second hemistich: "Denn eilends verflieht er (der Stolz des Lebens), und wir fliegen ebenso dahin."

67 Krüger, "Psalm 90," 194.

68 Seybold, "Zeitvorstellungen," 103. 
years are long rather than wide), or the much common rōb, "abundance" (which looks even more like a simplification). ${ }^{69}$

He has ורהבם = "but their boisterousness."

- "toil and nothingness" (Mühsal und nichtigkeit). Cf. Ps 10:7, Job 4:8, 5:6, and Isa 10:1. In most of its occurrences (55), עמל means the "the burden of labor." 70 Delitsch explains that all that during the life span was a source of pride, when correctly viewed is but עמל, in the sense that it is a burden and causes toil, and און, because it is without true substance and value. ${ }^{71}$ This perspective is at odds with that of Wisdom literature, "Wisdom poetry, on the whole, praises the relatively rare phenomenon of aging as evidence of righteous behavior and physical vigor. [Where does the quotation end?] Terrien notes that "the sapiental atmosphere of this strophe [10-12] however finds longevity quite independent from happiness since it is "only misery and inanity.", אוּן "need, misery" (noth) (Ps 55:4). ${ }^{73}$ One can find in Lexica that אָוּ means: distress one causes another; injustice toward another; trouble, discomfort; iniquity, sin; lie, deceit; and, delusion, especially by idols and their cults and oracles. ${ }^{74}$ Krüger has for עמל עמל ואון עמל עמון "toil and mischief" (Mühsal und Unheil).

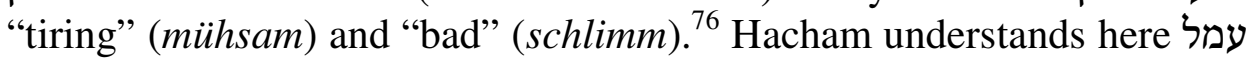
= "pain and suffering" (מכאובים ויסורים) = און = "vanity and naught" (הבל וריק).

- גזז "to cut") means in all the Semitic dialects "to pass." It can refer to ימי

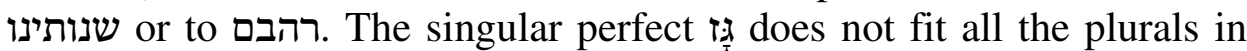
the verse. Qimchi takes it as being impersonal, but this is not satisfactory. The word ג stands out as the only singular term in the verse.

- חיש = "hastily" (eilends). The hapax legomenon infinitive adverb of the verb חיש חיש חישוּש (Deut 32:35, Ps 71:12). Malbim explains כי־גז חיש by describing the quick passage of time. He says that כי־גז חיש refers to "the flow of time that hastily speeds in its run and disappears

69 Goldingay, Psalms 3, 20.

70 S. Schwertner, “"āmāl »Mühsal«"” THAT 2: 332.

71 Delitzsch, Biblischer, 591.

72 Samuel Terrien, The Psalms, Strophic Structure and Theological Commentary (Grand Rapids: Eerdmans, 2003), 644.

73 De Wette, Commentar, 504.

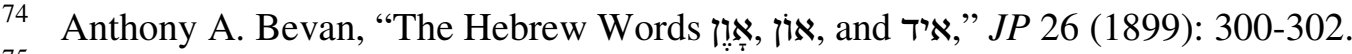

75 Krüger, "Psalm 90," 194.

76 Seybold, “Zeitvorstellungen," 103.

77 Hacham, תהילים,164-165. 
from existence each second; since constantly present moments become past moments."78 In that case the author could have said כי־גז חיש עתו or (דָחש Duhm seems to be reading, "slips away" (enteilt); obtaining "Denn es lauft, enteilt." "D9 Dahood argues that the meaning of חיש should be derived from the root "to rejoice" (Ugaritic ȟšt, “joy, pleasure”), and perhaps used in Qoh 2:25. ${ }^{80}$

- ג "and we fly there" (und wir flogen dahin). The term intensifies חיש by adding detail and the onomatopoeic sound at the end of the word suggesting a groan. ${ }^{81}$ The notion that "wir flogen fort, wir wurden auf Flügeln der Vargänglichkeit schnellen Flugs dahin getragen" is bizarre in the Tanach context. ${ }^{82}$ De Witte's rendering of ונעפה by "und wir fliegen" is too indefinite. 83 Schreiner translates ונעפה by "und wir fliegen ebenso dahin." ${ }^{84} \mathrm{He}$ finds support for this image in Isa 17:13. However, the image in Isaiah is based on actual observation of things that are swept away by wind. Anderson states that the "metaphor simply describes the swift passing of human life (cf. Job 20:8)," ${ }^{, 5}$ It is unconnected to the Egyptian notion that the human "soul" is like a bird. ${ }^{86}$

Krüger has for ונעפה "then we have [already] flown away" (dann sind wir [schon] davongeflogen). ${ }^{87}$ This interpretation of the hapax legomenon leaves many questions unanswered. Seybold observes that נעפה reflects

natürlich die Vorstellung vom Fliegen (nicht so sehr des Pfeils oder Vogels), vielmehr vom «Schuss» der Garnspule, die sich immer weiter abwickelt. Der feste Bildkreis des Verses könnte der Grund dafür sein, weshalb eine Vergleichspartikel fehlt. ${ }^{88}$

Malbim, Mikraot Gedolot (Jerusalem: Even Israel, 1992), ad loc.

79 Duhm, Psalmen, 226. Duhm says: "für das zweifelhafte á $\pi$. $\lambda \varepsilon \gamma$. schreibt mann wohl vorsichtiger mit Bickel u.a. הַחיש."

80 Dahood, Psalms 2, 325.

81 The "ah" ending is more common for the 1st person singular than for the 1 st person plural.

82 Delitzsch, Biblischer, 590.

83 De Wette, Commentar, 504.

84 Schreiner, "Erwägungen," 86.

85 Anderson, Psalms 2, 653.

86 Henri Frankfort, Ancient Egyptian Religion: An Interpretation (New York: Harper, 1996), 96ff.

87 Krüger, "Psalm 90," 194.

88 Seybold, "Zeitvorstellungen," 103. Cf. Job 7:6 and Isa 38:12. However, neither of the sources, used by Seybold in support of his understanding of נעפה, mentions "flying" or uses the root עוף. 
It is very difficult to see how «Schuss» der Garnspule could be associated with נעפה. Malbim struggled with the notion of "time" and assumed that "time" = "human life" (חיי האדם). As each moment of time passes so also does human life pass to the domain of nothingness (תחום האפס). ${ }^{89}$ Hacham suggests that time and space fly quickly and we fly with it and disappear. ${ }^{90}$ This cosmological notion makes no sense.

Even this partial analysis of the exegesis on v. 10 suggests a fundamental dichotomy. It seems as though the average reader and commentator were in main comfortable with understanding the message that the verse tries to convey. This turned parts of the verse into colloquial elements. However, considerable difficulties arose when one tried to anchor the general understanding in the MT. In that case, the unusual syntax, grammatical forms, hapax legomena, and incomplete metaphors combine to make an exegete's task formidable.

\section{PROPOSED SOLUTION}

Psalm 90 is one of the better known of the psalter, V, because of its function in various religious rituals and its observations on the human condition. The thematic, structural, theological, and historical problems that it posed have attracted considerable and continued interest of the religious and scholarly community. Unfortunately, this interest did not extend to the textual difficulties in MT. Thus, while v. 10 is widely known and frequently used colloquially, hardly any new exegetical ideas were advanced with regard to its textual difficulties and consequent interpretation. In this section a new understanding of v. 10 will be presented that exploits some well-established text-critical tools.

It is obvious to anyone with a modicum of Hebrew knowledge that v. 10a $\alpha$ is awkward. Verse 10a $\beta$ ewhardly adds anything n. From the thematic point of view, having both ages (70 and 80) does not make any substantial difference; man's life is finite and short in any case. If MT v. 10a $\alpha+10 \mathrm{a} \beta$ is the Psalmist's original formulation one may rightly wonder why he did not more cogently omit ימי שנותינו שבעים שנה and write. It seems as though the Psalmist was constrained by the accepted formulation of a popular text (or proverb) that he borrowed and used. ${ }^{91}$ This suggests authorial indecision (or, conservatism) and a compromise solution that produced a conflated text. Thus, it is

89 Malbim, Mikraot Gedolot (Jerusalem: Even Israel, 1992), ad loc. Malbim's concept of death, as expressed in the interpretation of v. 10, is scientifically modern and unusual for a religious commentator of his time.

90 Hacham, תהילים (תפים עמו ונעלמים."

91 תהילים, 200. Hayot believes that the original was ימים שנותינו שבעים שנה and בהם comes from a later variant version for רהבם, which was noted on the margin and later included in the text. 
likely that v. $10 \mathrm{a} \alpha+10 \mathrm{a} \beta$ is the end-result of conflating two colloquial sayings: שנותינו "the days of our vigor [are] seventy years”), and ("מי כחיחנו: שבעים שנה בגבורת שמונים שנה ("Our years with might [are] eighty years”). Perhaps,

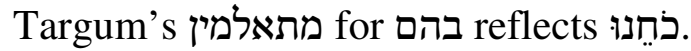

One readily notes that v. 10 , in essence, repeats the main idea expressed in vv. 8-9. Thus, it is reasonable to consider v. 10 as mentioning a proverb that supports the idea presented in vv. 8-9. The author had, however, to decide which of two popular proverbs to use. He opted to conflate the two proverbs; placing the two proverbs practically side by side:

\begin{tabular}{|c|c|c|}
\hline separate & שנותינו בגבורת שמונים שנה & ימי כחָנוּ שבעים שנה \\
\hline conflated & ואם בגבורת שמונים שנה & ימי שנותינו כחַנוּ שבע \\
\hline
\end{tabular}

where the conditional ואם serves as a conjunctive.

Conflation of equally valid, or similarly venerated, texts was apparently a standard practice among scribes in ancient Israel. Zimmermann argued that,

$\ldots$, as one may reasonably surmise, the scribes who guarded the text so reverently, letter by letter, would have been loath to discard variant readings which may have been striking alternatives.

The present writer takes the view that, for a brief short-lived period in the transmission of the Hebrew text, a school of proto-Masoretes attempted to imbed in the text variant readings. For the most part, it was probably assumed that the reader would tacitly recognize that a particular verse had variant readings. Of course, these proto-Masoretes could not conceive or did not indulge in the footnotes or apparatus of which a modern editor avails to his self. By and large, however, their method of marking variants consisted of assigning them the following position in the text:

(i) at the end of a verse

(ii) at, or as close as possible, to the cesura (the later official Atnahta)

(iii) side by side in the text. ${ }^{92}$

The conflated text ימי שנותינו כחיזנו שבעים שנה ואם בגבורת שמונים שנה is certainly awkward. This might have been intentional; as Zimmerman notes "it was probably assumed that the reader would tacitly recognize that a particular verse had variant readings." However, it is possible that a later copyist, coming across the word כחנו in a densely written indistinct Hebrew manuscript, mis-

92 Frank Zimmermann, "The Perpetuation of Variants in the Masoretic Text," JQR 34 (1943/44): 460-461. Zimmerman provides many examples of such conflations. He says: "These examples are sufficient to show, it is hoped, that many texts, far from being corrupt or redundant, contain masoretic variations." See Zimmermann, "Perpetuation," 472. Cf. Aron Pinker, "Ben Zoma's Query on Genesis 1:7: Was It What Drove Him Insane?” Judaism 55/3-4 (2006): 51-58. 
conceived it as the pronominal בהם; the awkwardness of the conflated text contributing subconsciously to the misconception.

The confusion of the two words כחנו and and be easily rationalized. Confusion of $ב$ and is well attested in the Tanach. ${ }^{93}$ In the Hebrew orthography of about 400 B.C.E. the left leg of current ה ב ב top. The ancient looked like the current $\pi$ with a top somewhat extended to the left. ${ }^{94}$ Confusion of $\mathrm{n}$ and $\Pi$ was quite likely and occurs in the Tanach. ${ }^{95}$ Finally, the ligature $ם$ has been recognized by biblical scholarship and is כחנו attested in the Tanach. ${ }^{96}$ From a text-critical point of view confusion of with בהם is certainly possible. Moreover, a כח category occurs in Pirkei Abot 5:21 division of ages, albeit it is associated with the age of thirty, which is not referred to in v. 10. The age of seventy is categorized by שֶיבָה ("graying"), which would also indicate a phase of vigor.

The pair כח וגבורה occurs in 1 Chr 29:12 and 2 Chr 20:6, and they are

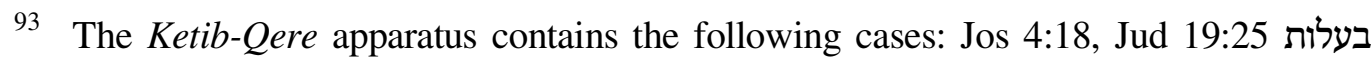

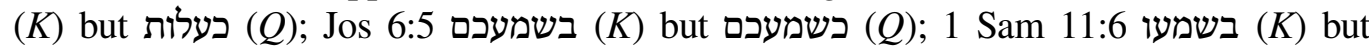

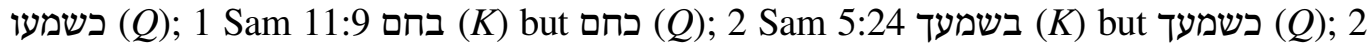

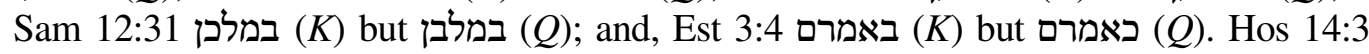

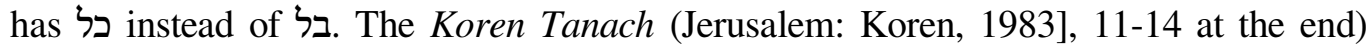

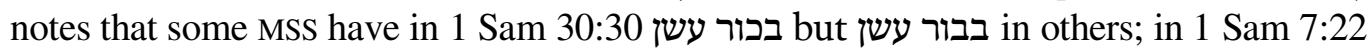

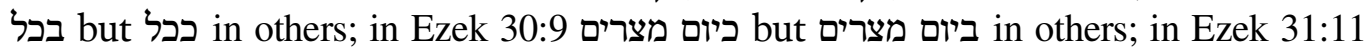
כהתחברך in others; in 2 Chr 20:37 בתף מתף in others; in Job 21:12 ברשעו but ברשעו but בהתחברך in others. Codex Petersburg and Codex Allepo have בתף ברדי but Mikraot

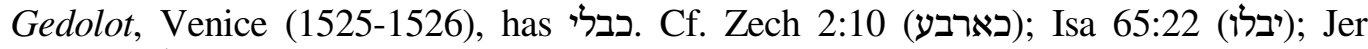
18:17 (בלשון); Hos 7:12 (כאשר); and, Ezek 16:36 (וכדמי).

94 Frank M. Cross, "The Development of the Jewish Scripts," in The Bible and the Ancient Near East, Essays in Honor of W. F. Albright (ed. G. Ernest Wright; Garden City, N.Y.: Doubleday, 1961), 137, Fig. 1.

95 The Ketib-Qere apparatus attests to the following cases of $\pi$ confusion: 2 Sam

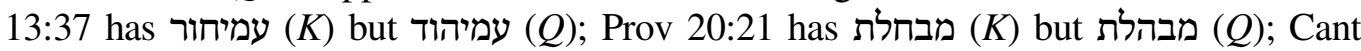

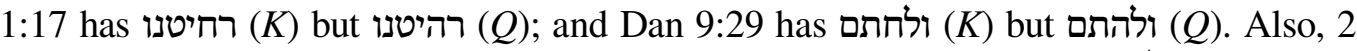

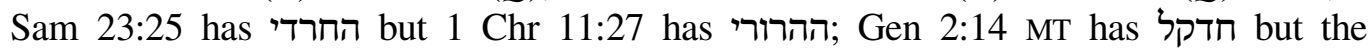

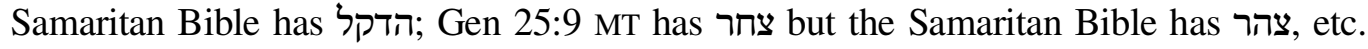
Torczyner (Tur-Sinai) mentions the following: in Prov 1:21 הומיות instead Prov

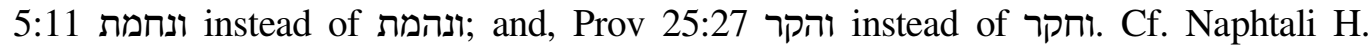
Torczyner (Tur-Sinai), משלי שלמה (Tel Aviv: Yavneh, 1947), 104. See also James Kennedy and Nahum Levison, An Aid to the Textual Amendment of the Old Testament (Edinburgh: T\&T Clark, 1928), 17.

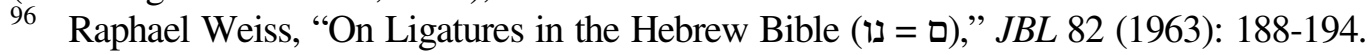

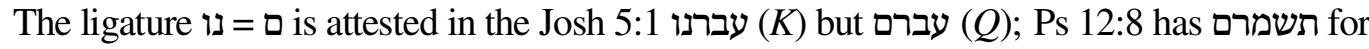

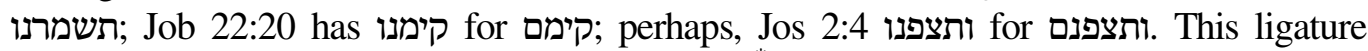
occurs also in the Qumran scroll 11QPs ${ }^{\mathrm{a}}$ [Plate 8*, Col. X, Lines 1, 6]. Cf. Emanuel Tov, The Textual Criticism of the Bible: An Introduction (Jerusalem: Mosad Bialik, 1989), 167. The closely related ligature בי = מ is attested in Job 34:36 and 2 Kgs 5:13. 
parallel in Mic 3:8. Thus there is support in the Tanach for the suggested parallelism between גבורת and כבורת This parallelism could provide also some insights into the meaning of גבורת. In the Tanach, the plural feminine noun i: iּבוּרוֹת is used to describe the mighty deeds of God (Deut 3:24, Pss 20:7, 71:16, $106: 2,145: 4,12,150: 2$, and Isa 63:15). Prolonging man's life to eighty years would not seem to be in this category. Moreover, the only defectiva גבורת in our verse suggests that it might have resulted from a ת confusion in the Hebrew square-script. This confusion is attested in the Ketib-Qere apparatus. ${ }^{97}$ It is also possible that בגבורה was written originally in the abbreviated form בגבור. G. R. Driver notes that "A very common abbreviation is the omission of the feminine singular." 98 Perhaps, at a later time, when the abbreviations were filled in, בגבור was completed by adding erroneously a $ת$ at the end (under the influence of the many גבורות), rather than a הת ה. Whatever the specific mechanism for the error might have been, it is obvious that it could have occurred naturally.

Understanding MT v. $10 \mathrm{a} \alpha+10 \mathrm{a} \beta$ as stemming from a conflation and being originally ימי שנותינו כחיזנו שבעים שנה ואם בגבורה שמונים שנה, though somewhat awkward Hebrew, has considerable advantages: (1) it explains the origination of the construct ימי־שנותינו; (2) it removes the impossible

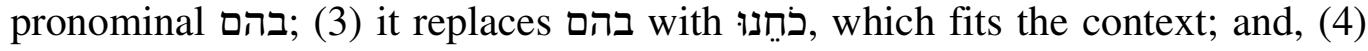
כחיזנו corrupted version of an original, which intended to say:

Whether

The days of our vigor [are] seventy years

ימי

or

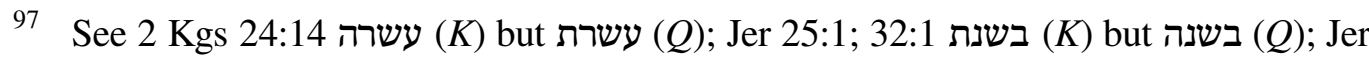

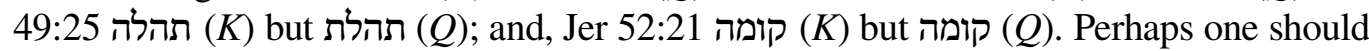

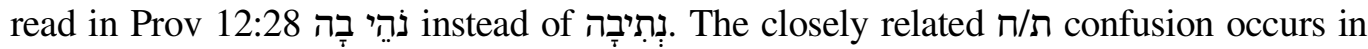

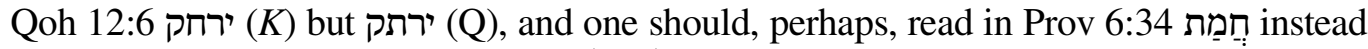
of משתמִת. Cf. Torczyner (Tur-Sinai), משלי שלמה, 106-107.

98 Godfrey R. Driver, “Once Again Abbreviations," Text 2 (1962): 78. For instance,

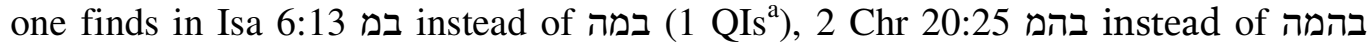

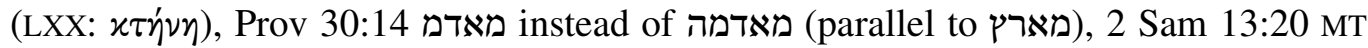

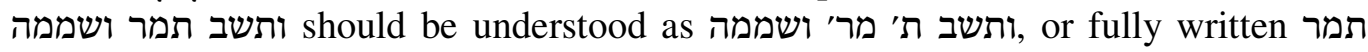
מרה ושממה ותשב, etc.. Driver, "Once Again," 93-94, notes that "the recognition of hidden abbreviations in the MT can thus be used for the recovery of the original text without emendation. The method, however, must be used with circumspection and due regard for the rules. These are, briefly, that only certain categories of terms are subject to abbreviation, namely: terminations, including pronominal elements; independent pronouns; ...." 
516 Pinker, "Psalm 90:10," OTE 28/2 (2015): 497-522

Our years with might [are] eighty years

שנותינו בגבורה שמונים שנה

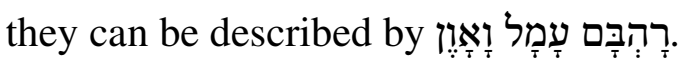

Though רהב occurs in many cognate Semitic languages its etymology is not clear. The word might be related to the ferocious and proud Assyrian mythical sea monsters. Schunck says,

Innerhalb des AT begegnet dieses Wort außer im vorliegenden Zusammenhang [Jes 30 7] noch in Jes 519 Hi 9132612 Ps 874 und 89 11. Eine genauere Untersuchung dieser Stellen läßt unschwer erkennen, daß es eine zweifache Verwendung des Namens gegeben hat: 1. der appellativen Grundbedeutung »Unruhe«, »Aufregung « entsprechend als Bezechnung für ein mythisches Ungeheuer (Ps 8911 Jes 519 Hi 91326 12) und 2. als Bezechnung für Ägypten (Ps 87 4). ${ }^{99}$

In the Tanach, the verb רהב is used in the sense "act stormily, boisterously, arrogantly." 100 It seems prudent to derive the meaning of the hapax legomenon רָהב (noun) from the sense that the well-attested verb In our verse, the noun רהַב could mean "pride" and be a metonymic reference to that which one is proud of.

The pair ואון עמל און occurs frequently in the Tanach (Isa 10:1; 59:4; Pss 10:7; 55:11; 7:15; Job 4:8; 15:35; Hab 1:3). DCH translates as "misfortune" when it is paired with עמל in Hab 1:3, Num 23:21, Job 5:6, Ps 55:11, 90:10, but not elsewhere. ${ }^{101}$ The Theological Dictionary of the Old Testament explains the pairing of עמון עמל as one being the logical consequence of the other; עמל "trouble" is the result of "inequity." (on Hab 1:3) says that ועמל און is a general term encompassing all the depravity and sin that man is capable of.

The masculine noun עָמָל (once as feminine in Qoh 10:15) means "trouble, labor, toil." From this meaning are derived "weariness," "trouble" and "vexation." Gesenius notes that some render עמל as "sin, wickedness (i.e., און)" (Num 23:21; Isa 10:1), but he believes that the meaning of "vexation" is also possible in both places. ${ }^{103}$ In our case too, the context of the verse admits "vexation" as the meaning of עמל. Andersen understands עמל as conveying the agony of body or mind that is humanity's inevitable lot (Job 5:7) and

99 Klaus-Dietrich Schunck "Jes 30 6-9 und die Deutung der Rahab im Alten Testament," ZAW 78 (1966): 53.

${ }^{100}$ Cf. BDB, 923a.

$101 \mathrm{DCH}, 154$.

102 TDOT 1:142.

103 H. Wilhelm F. Gesenius, Gesenius' Hebrew-Chaldee Lexicon to the Old Testament (based on the 1847 ed.; Grand Rapids: Baker, 1979), 21. 
particularly the weariness of a person worn out by work and cares of this life. It is spiritual torture, weariness, exhaustion, enervation, or a loss of vitality that is caused not by any physical tiredness but by the hostile behavior of one's fellows. ${ }^{104}$

The masculine noun און, in absolute state, means "trouble, sorrow, wickedness." Johnson understands it as "meaningless misfortune."105 Some have suggested that און means "trouble" when it is coupled with עמל. feels that און expresses human wickedness in the form of deceit, misrepresentation, deliberate misleading of someone so as to do harm or cause him און could have it is probably used here in the sense of "sorrow." Choosing describe the nature of human life, the psalmist may have intended also to imply its homophone אבן "stone," the indifference that humans so often exhibit.

Weiser observes that "the familiar verse which pronounces a completely pessimistic verdict on the brevity and transience of life ... does not leave any room for even a mere attempt to take a more positive attitude to life."108 However, the quick passage of one's life cannot be the cause for its being עמל כואון Thus, Th $10 \delta$ is not the beginning of a cause as it is in vv. 8 and 9; it cannot mean "for, because." Moreover, the context does not admit the other

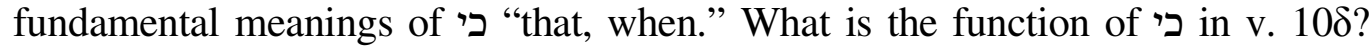
The form זגז only in our verse. Other forms of the root can be found in Num 11:31, Ps 71:6, and perhaps in Nah 1:12. The root is kindred to גז "cut, terminate," sharing with

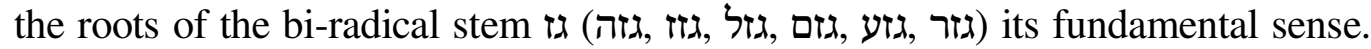
In our verse the singular is odd, since all the other words are plurals.

The difficulties with כג בז and singular be resolved if it is recognized

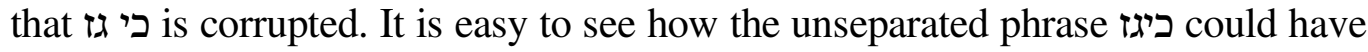
been perceived being the word נגוז; perhaps reflected in Vulgate's transivimus. While the $\mathrm{J}$ confusion is not attested in the Ketib-Qere apparatus it is very likely because of the orthographic similarity between the two letters in both the Hebrew paleo-script and square script. Such confusion might be the cause for the difference in Isa 49:4 between אכן אכ 10Is ${ }^{b}$ and Codex Leningrad. We find

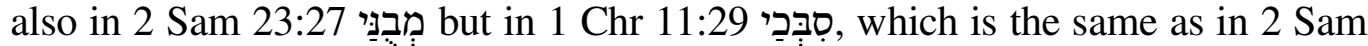

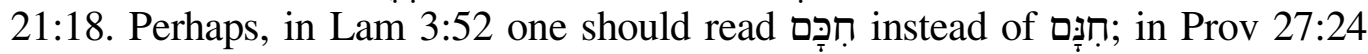

${ }^{104}$ Francis I. Andersen, Habakkuk (AB 25; New York: Doubleday, 2001), 113, 115.

105 Marshall D. Johnson, “The Paralysis of Torah in Habakkuk 1:4,” VT 35 (1985): 257-266.

106 J. M. Powis Smith, William H. Ward and Julius A. Bewer, A Critical and Exegetical Commentary on Micah, Zephaniah, Nahum, Habakkuk, Obadiah and Joel (ICC; Edinburgh: T \& T Clark, 1985), 8.

107 Mária Eszenyei Szeles, Habakkuk \& Zephaniah, Wreath and Mercy (ITC; Grand Rapids: Eerdmans/Handsel, 1987) 18.

108 Weiser, Psalms, 599. 


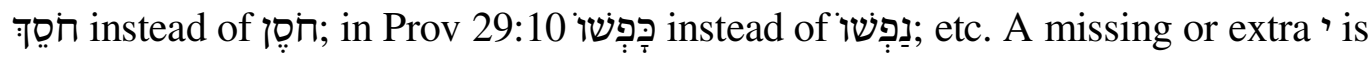
attested in about 130 cases of the Ketib-Qere apparatus. Thus, it is possible that MT presents a mistaken reading of the original נָזָ, which is of the same form as

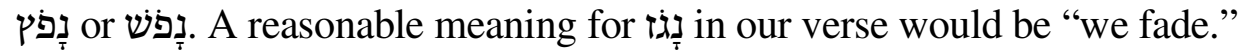

The adverb חיש is a hapax legomenon, which was apparently derived from the well-attested verb חוש I (Ps 71:12), which means "haste, make haste." This meaning gives the phrase נָזגז חִיש the sense "we fade quickly." However, the psalmist could have obtained this sense by using the well-known adverb מַהֵ Why did he opt for the hapax legomenon חיש? Perhaps, this choice is not accidental. It could be that the psalmist intended the reader to associate intuitively with חוש II "feel, enjoy." As the Ketib-Qere (חושה-חישה) in Ps 71:12 indicates, the two words were probably pronounced the same way, and consequently confused. The psalmist could have expected his sophisticated readers appreciate his clever choice of the word חיש, to indicate both the quick passing of life and the deterioration of senses.

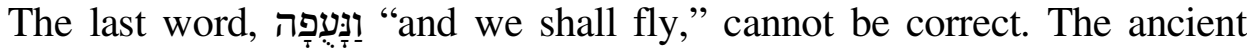
could not have imagined man flying. In the Tanach only locust (Nah 3:16), birds (Deut 4:17, Isa 31:5, Hab 1:8, Hos 9:1, Prov 23:5, 26:2, Ps 55:7) and angels (Isa 6:2, 6, Dan 9:21) are mentioned as having the capability to fly. ${ }^{109}$ In Ps 55:7 the psalmist asks rhetorically: "Can someone give me wing as a dove, so that I would fly and settle down?" The answer to this question is an obvious "No." The psalmist has to remain in his place; man cannot fly. Upon his death man returns to earth, and goes down to Sheol. Man could see objects fly, and could fantasize about angels flying, but could not imagine himself fly. No metaphor of this kind

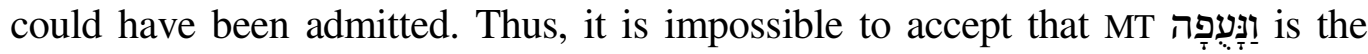
original reading.

Fortunately, a transposition of two adjacent letters in ונעפה results in the word ונפעה "and we shall groan." Text-criticism is well aware of the many metathesis cases in the Tanach, and considers this a minor emendation. would be the qal 1st person plural imperfect of פעה "groan (onomatopoeic)." In

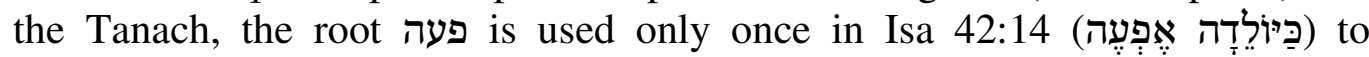
describe a woman's constrained groans during child delivery. However, Arabic has بغى , بعى, and Aramaic has פעא, both with the sense "bleat." The root is also

\footnotetext{
109 Jehuda Feliks, The Animal World of the Bible (Tel Aviv: Sinai, 1962), 108. Feliks observes: "The flying serpents' in the Book of Isaiah [14:29, 30:6] are likewise present in the literature of the people of the East. Herodotus, the historian, describes them as if they were real animals: 'The flying serpents live in Arabia. Countless numbers are found near the frankincense trees; they migrate to Egypt where they are eaten in their thousands by Glossy Ibises.' As yet, no flying snake has ever been found in Israel or for that matter anywhere else on the earth."

110 Naphtali H. Tur-Sinai, הלשון והספר (vol. 2; Jerusalem: Bialik Inst., 1959), 106-149.
} 
used in the Talmud and Midrashic literature. ${ }^{111}$ It is possible that the rarity of the verb in the Tanach was a contributing factor for the scribal metathesis, which resulted in the difficult MT ונעפה.

The word נִפְעֶה gives an excellent contextual fit when it is recognized that the groan that it refers to is the "death rattle." This rattle, now known clinically as terminal respiratory secretions or simply terminal secretions, was frequently witnessed by the ancients and associated with death. A death rattle is produced by a person near death because fluids (saliva and bronchial secretions) accumulate in the throat and upper chest, and he has no more the

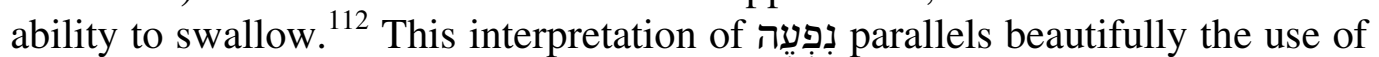

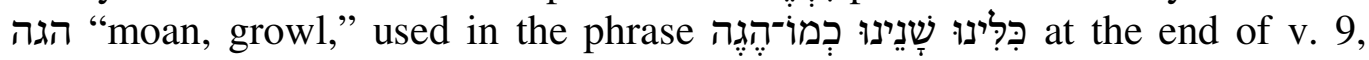
perhaps giving הגה a more nuanced meaning. Note also the onomatopoeic sound at the end of the word. It seems that the last colon of v. 10 speaks poignantly of the final stage in a human's life "we fade quickly, and we rattle ..."

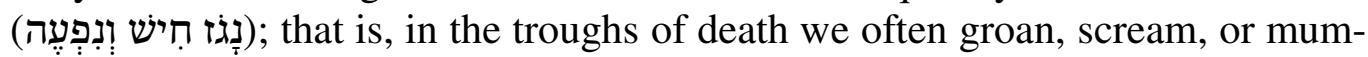
ble loudly.

The solutions that have been suggested for the difficulties encountered in v. 10, lead to the following reading:

The days of our vigor [are] seventy years

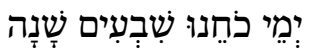

Or

Our years with might [are] eighty years And their pride [is] vexation and sorrow. We fade quickly, and we rattle

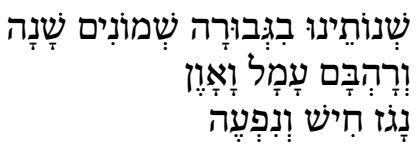

This reading can be paraphrased:

The years in which we have strength are about seventy (or, when particularly mighty they are eighty). That which one is proud of, is in retrospect only vexation and sorrow. We quickly fade, lose our senses, and make the death rattle...

\section{CONCLUSION}

Verse 90:10 seems to consist of popular sayings about the brevity and insignificance of human life. The psalmist combined these sayings and wove them into a powerful premise for his fundamental plea in v. 13: "Return, O God! // Till when? // And have mercy upon Your servants (עבובה יהוה עד־מתי והנחם על־)." עבדיך)."

111 Jastrow, 1202a.

112 Hans Wildiers and Johan Menten, "Death Rattle: Prevalence, Prevention and Treatment," JPSM 23/4 (2002): 310-17. 
The critical element in the plea is the temporal phrase "Till when?" (עד־ מתי It connects with the temporal elements in almost each of the preceding verses. In v. 10, the gloomy perspective on life, its shortness and misery, is the basis for the psalmist's plea that God returns to show grace to his servants. Repeating the life-spans of seventy and eighty, the psalmist

articulates a life-consciousness determined by sadness, by melancholy, the experience of God's distance-the same complaint of the great, universal lamentation of Ecclesiastes, lifted to heights of abstraction, an ahistorical adjuration of what cannot be changed. ${ }^{113}$

Man has to die, but he cannot fly. Upon death, "dust returns to the earth as it was, and the breath returns to God who gave it" (Qoh 12:7)—nothing flies. Commentators seem to have missed this point. The suggested reading וְנְפְעִ (and we rattle ...) for MT וַנְּעָפָה provides an eminently suitable word for the

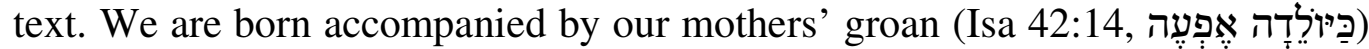
and we die with a death rattle (Ps 90:10, וְנְפְֶֶ). The symmetry is striking.

\section{BIBLIOGRAPHY}

Andersen, Arnold A. Psalms 73-150. Volume 2 of The Book of Psalms. Grand Rapids: Eerdmans, 1992.

Andersen, Francis I. Habakkuk. Anchor Bible 25. New York: Doubleday, 2001.

Barzilai, Gabriel. שבעים שנה' מירמיהו ועד דאניאל: סמנטטיקה, פרשנות ואפוקליפטיקה'. Beit Mikra 59/2 (2014): 41-59.

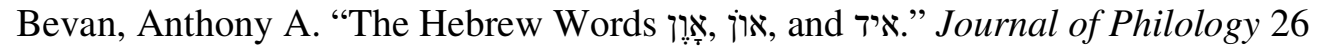
(1899): 300-302.

Botterweck, G. Johannes and Helmer Ringgren, eds. Theological Dictionary of the Old Testament. Translated by John T. Willis, Geoffrey W. Bromiley and David

E. Green. 8 vols. Grand Rapids: Eerdmans, 1974.

Brenton, Lancelot C. L. The Septuagint with Apocrypha: Greek and English. Peabody: Hendrickson, 1987.

Briggs, Charles A. The Book of Psalms. Volume 2. International Critical Commentary. Edinburgh: T. \& T. Clark, 1960.

Brown, Francis, Samuel R. Driver and Charles A. Briggs. The Brown-Driver-Briggs Hebrew and English Lexicon. Peabody: Hendrickson, 2001. Reprint of the 1906 edition.

Clifford, Richard J. "Psalm 90: Wisdom Meditation or Communal Lament." Pages 190-205 in The Book of Psalms, Composition and Reception. Vetus Testamentum Supplements 99. Edited by Peter W. Flint and Patrick D. Miller. Leiden: Brill, 2005.

Clines, David J. A., ed. The Dictionary of Classical Hebrew. Sheffield: Sheffield Academic Press, 1993.

Cross, Frank M. "The Development of the Jewish Scripts." Pages 133-202 in The Bible and the Ancient Near East: Essays in Honor of W. F. Albright. Edited by G. Ernest Wright. Garden City, N.Y.: Doubleday, 1961.

113 Jens, "Psalm 90." 
Dahood, Mitchell J. Psalms 1-50. Volume 1 of Psalms. Anchor Bible 16. Garden City: Doubleday, 1968.

. Psalms 51-100. Volume 2 of Psalms. Anchor Bible 17. Garden City, Doubleday, 1968.

Delitzsch, Franz. Biblischer Kommentar über die Psalmen. 5th edition. Leipzig: Dörffling Franke, 1894,

De Wette, Wilhelm M. Commentar über die Psalmen. 4th edition. Heidelberg: Mohr, 1836.

Driver, Godfrey R. "Once Again Abbreviations.” Textus 2 (1962): 76-94.

Duhm, D. Bernhardt. Die Psalmen erklärt. Freiburg: Mohr, 1899.

Feliks, Jehuda. The Animal World of the Bible. Tel Aviv: Sinai, 1962.

Frankfort, Henri. Ancient Egyptian Religion: An Interpretation. New York: Harper, 1996.

Gesenius, H. Wilhelm F. Gesenius' Hebrew-Chaldee Lexicon to the Old Testament. Based on the 1847 edition. Grand Rapids: Baker, 1979.

Goldingay, John. Psalms: Psalm 90-150. Baker Commentary on the Old Testament. Grand Rapids: Baker, 2008.

Grätz, Heinrich. Kritischer Kommentar zu den Psalmen. Breslau: Schottlaender, 1882.

Gurney, Oliver R. and Jacob J. Finkelstein. The Sultantepe Tablets. Vols. I/II. London: British Institute of Archaeology at Ankara, 1957/1964.

Hacham, Amos. תהילים חלק ב'. Jerusalem: Mosad HaRav Kook, 1987.

Ha-GRA. ליקוטי הגר" 'Mikraot Gedolot. Jerusalem: Even Israel, 1992.

Ha-Meiri. המאירית. Mikraot Gedolot. Jerusalem: Even Israel, 1992.

Hayot, Zvi P. ספר תהילים. Jerusalem: Makor, 1970. Reprint of $1^{\text {st }}$ edition 1902.

Hossfeld, Frank-Lothar and Erich Zenger. Psalms 51-100. Volume 2 of $A$ Commentary on Psalms 51-100. Minneapolis: Fortress Press, 2005.

Jastrow, Marcus. Dictionary of the Talmudim the Talmud Babli and Yerushalmi and the Midrashic Literature. Brooklyn: Traditional Presss, 1903.

Jenni, Ernst, with Claus Westermann. Theologisches Handwörterbuch zum Alten Testament. 2 vols. Stuttgart: Theologischer Verlag, 1971-1976.

Jens, Walter. "Psalm 90: On Transience.” The Lutheran Quarterly 9 (1995): 177-189.

Johnson, Marshall D. "The Paralysis of Torah in Habakkuk 1:4." Vetus Testamentum 35 (1985): 257-266.

Kennedy, James and Nahum Levison. An Aid to the Textual Amendment of the Old Testament. Edinburgh: T \& T Clark, 1928.

Köhler, Ludwig. Der hebräische Mensch: eine Skizze. Tübingen: Mohr, 1953.

Koren Tanach. Jerusalem: Koren, 1983.

Kraus, Hans-Joachim. Psalmen. Volume 2. Neukircchen-Vluyn: Neukirchener, 1966.

Krüger, Thomas. "Psalm 90 und die Verganglichkeit des Menschen." Biblica 75 (1994): 191-219.

Lamsa, George M. Holy Bible from the Ancient Eastern Text. San Francisco: Harper \& Row, 1933.

Meir Leibush ben Yechiel Michel. Mikraot Gedolot. Jerusalem: Even Israel, 1992.

Malamat, Avraham. History of Biblical Israel: Major Problems and Minor Issues. Leiden: Brill, 2001.

Müller, Hans-Peter. "Der 90. Psalm: Ein Paradigma exegetischer Aufgaben." Zeitschrift für Theologie und Kirche 81/3 (1984): 265-285. 
522 Pinker, "Psalm 90:10," OTE 28/2 (2015): 497-522

Pinker, Aron. "The Ligature עז ע in Qohelet 6.3." Bible Translator 62/3 (2011): 151-164.

."The Number 40 in the Bible." Jewish Bible Quarterly 22/3 (1994): 163-172. "Isaiah 30,7b." Biblische Notizen 136 (2008): 31-44. . "Ben Zoma's Query on Genesis 1:7: Was It What Drove Him Insane?" Judaism 55/3-4 (2006): 51-58.

Reider, Joseph. "Etymological Studies in Biblical Hebrew." Vetus Testamentum 2/2 (1952): 113-130.

Schnocks, Johannes. Vergänglichkeit und Gottesherrschaft. Berlin: Philo, 2002.

Schreiner, Stefan. "Erwägungen zur Struktur des 90. Psalms.” Biblica 59/1 (1978), 80-90.

Schunk, Klaus-Dietrich. "Jes 30 6-9 und die Deutung der Rahab im Alten Testament." Zeitschrift für die alttestamentliche Wissenschaft 78 (1966): xxx-xxx.

Seybold, Klaus. "Zu den Zeitvorstellungen in Psalm 90.” Theologische Zeitschrift 53 (1997): 99-108.

Sforno. (ספורנו). Mikraot Gedolot. Jerusalem: Even Israel, 1992.

Smith, J. M. Powis, William H. Ward and Julius A. Bewer. A Critical and Exegetical Commentary on Micah, Zephaniah, Nahum, Habakkuk, Obadiah and Joel. Edinburgh: T\&T Clark, 1985.

Szeles, Mária Eszenyei. Habakkuk \& Zephaniah, Wreath and Mercy. Int. Theol. Commentary. Grand Rapids: Eerdmans/Handsel, 1987.

Tate, Marvin E. Psalms 51-100. Word Biblical Commentary 20. Dallas: Word Books, 1990.

Terrien, Samuel. The Psalms, Strophic Structure and Theological Commentary. Grand Rapids: Eerdmans, 2000.

Torczyner (Tur-Sinai), Naphtali H. משלי שלמה. Tel Aviv: Yavneh, 1947.

Tov, Emanuel. The Textual Criticism of the Bible, An Introduction. Jerusalem: Mosad Bialik, 1989.

Tur-Sinai, Naphtali H. הלשון והספר. Volume 2. Jerusalem: Bialik Inst., 1959.

Weiser, Artur. The Psalms: A Commentary. London: SCM Press, 1971.

Weiss, Raphael. "On Ligatures in the Hebrew Bible (נו $=$ ( $)$." Journal of Biblical Literature 82 (1963): 188-194.

Westermann, Claus. "Das 90. Psalm." Pages 344-350 in Forshung am Alten Testament. Edited by Claus Westermann, München: Chr. Kaiser, 1964.

Wildiers, Hans and Johan Menten. "Death Rattle: Prevalence, Prevention and Treatment." Journal of Pain and Symptom Management 23/4 (2002): 310-17.

Zerafa, Pietro P. “The Old Testament Life Span.” Angelicum 65 (1988): 99-116.

Zimmermann, Frank. "The Perpetuation of Variants in the Masoretic Text." Jewish Quarterly Review34 (1943/44): 459-474.

Aron Pinker, 11519 Monticello Ave., Silver Spring, Md., 20902, USA. 